\title{
Evaluation of Earthen Nala Bund in Small Watershed: A Case Study
}

\author{
H. N. Bhange*, S. S. Idate, B. L. Ayare, R. M. Dharaskar, G. G. Kadam and P. R. Kolhe \\ Department of Soil and Water Conservation Engineering, College of Agricultural Engineering \\ and Technology, DBSKKV, Dapoli- 415 712, Dist. Ratanagiri, MS,, India \\ *Corresponding author
}

\begin{abstract}
A B S T R A C T
Evaluation of Earthen Nala Bund in Kherdi watershed was undertaken to study the earthen nala bund as a water harvesting structures for its safety and economic feasibility. The water harvesting structures need to be tested for hydrological, hydraulic and structural design before execution so as to ensure their proper design. For the evaluation of earthen nala bund constructed by the Department of Agriculture, Government of Maharashtra in the year 2010-11 at Kherdi watershed in Dapoli Tahsil was selected. The data regarding watershed characteristics for Kherdi was obtained from Taluka Agricultural Office and existing dimensions were obtained from field visit. The design dimensions were compared with the design dimensions obtained by Department of Agriculture. The result of the study shows that, peak discharges considered by the Department of Agriculture was found to be too higher than the peak runoff obtained by using rational method under hydrological design of the structure. The dimensions of emergency flood spillway were selected in such a way that the discharge passing through flood spillway is greater than peak runoff rate. The total earthwork $\left(1313.85 \mathrm{~m}^{3}\right.$ and $\left.1857 \mathrm{~m}^{3}\right)$ for the nala bund was computed. In stability analysis, selected and designed dimensions of nala bunds were found to be safe from stability analysis.
\end{abstract}

\section{Introduction}

Water harvesting system consists of collection and storing excess runoff from the catchment area in a suitable reservoir and its subsequent use for irrigation of crops. It can be achieved by gully plugging, construction of structures like farm ponds, small check dams, nalas bunds, percolating tank etc. The structures are integral part of soil and water conservation activities and are important components of watershed development and management programmed. In Konkan region average annual rainfall is about $3000 \mathrm{~mm}$. Out of total precipitation, 80 per cent contributes as runoff, 16 per cent interception and other losses and 4 per cent as ground water recharge.

But due to high intensity of rainfall and steep land slopes of hilly terrain, most of the rainwater goes quickly as the surface runoff and causes severe soil erosion. Also the water infiltrated into the soil flows laterally at high 
rates due to high permeability of the substrata. Ultimately the streams get dried and water table goes very deep in the summer season, leading to the deficiency of water available for irrigation and even for drinking purpose. Konkan region constitutes $10 \%$ of the geographical area of Maharashtra state and receives $46 \%$ of the rainfall of Maharashtra.

Farmers of Konkan region are lacking in irrigation facilities and forced to take only one rain fed crop in the year. This has put the rural people in vicious cycle of 'poverty-low purchasing power-low investment-less productivity-poverty'. To overcome this problem, development of land and water resources through scientific and integrated approach on watershed basis is necessary (Mahale, et al., 2004). Hence, harvesting and harnessing the runoff water has become very important aspect.

The department of Agriculture, Maharashtra State has simplified the design and developed certain norms and prepared ready reckoned tables according to field conditions. The present study on evaluation of nala bund in selected watershed was undertaken with an objective to compare and evaluate the design parameters of selected earthen nala bund with standard design under similar hydrological condition.

\section{Materials and Methods}

The basic data regarding evaluation of earthen nala bunds constructed in 2008-09 watershed area 40.10 ha under the NWDP by the Department of Agriculture, Govt of Maharashtra. Storage volume claimed by Department of Agriculture, TCM 5.61.This evaluation was done during the year 20102011. One earthen nala bund was situated at Kherdi which have been constructed in the area of DapoliTahsil of Ratnagiri district.

\section{Design of earthen nala bund}

\section{Calculation of total volume of runoff}

Total volume of runoff was calculated by using following formula,

Total volume of runoff $=$ Runoff depth $\times$ Area of watershed

\section{Storage volume at crest}

Storage volume of earthen nala bund was calculated by using following formula (Tideman, 2003)

Storage volume $=0.4 \times \mathrm{A} \times \mathrm{D}$

Where,

$$
\begin{aligned}
& A=\text { water spread area }, \text { ha } \\
& D=\text { Maximum depth of water, } m
\end{aligned}
$$

\section{Determination of spillway dimensions}

Spillway should be designed such that the design peak discharge is less than or equal to spillway discharge.Design peak discharge was estimated by using Rational method

\section{Hydraulic design of earthen nala bund}

\section{Determination of spillway dimensions}

Spillway should be designed such that the design peak discharge is less than spillway discharge.

$\mathrm{Q}_{\mathrm{p}} \leq$ spillway discharge

$\mathrm{Q}_{\mathrm{p}} \leq$ C.L.H $\mathrm{H}^{3 / 2}$

Where, $\mathrm{Q}_{\mathrm{p}}=$ Peak discharge, $\mathrm{m}^{3} / \mathrm{s}$

$\mathrm{C}=$ Coefficient for rectangular weir

$\mathrm{L}=$ Length of crest for the flood spillway, $\mathrm{m}$

$\mathrm{H}=$ Flow depth in flood spillway, $\mathrm{m}$ 


\section{Height of embankment}

\section{Gross height (H)}

Gross height $=$ Normal water level + Gross freeboard + Consolidation height

The gross freeboard was estimated as

Gross freeboard $=$ Flow depth in flood spillway + Net freeboard

\section{Net freeboard}

The net freeboard for the nala bund was estimated as,

Net freeboard $=$ Wave height + Frost depth

\section{Wave height}

The height of wave for fetch was calculated by Hawksley's formula (Schwab et al., 1981)

$\mathrm{h}=0.014(\mathrm{Df})^{0.5}$

Where, $\mathrm{h}=$ Height of wave in metres from F.S.L. to crest and

Df $=$ Fetch or exposure in metres

\section{Consolidation height}

Consolidation settlement allowance was kept as $5 \%$ of height of nala bund al., 1990).

(Singh et

Gross height of embankment $=$ Normal water level + Gross freeboard + Consolidation height

\section{Top width of nala bund}

Top width of nala bund was estimated by using the equation.

$$
\mathrm{W}=\frac{\mathbf{H}}{5}+\mathbf{1 . 5}
$$

Where, $\mathrm{W}=$ Top width of nala bund, $\mathrm{m}$ and $\mathrm{H}=$ Gross height of nala bund, $\mathrm{m}$

The top width was kept constant throughout the length of the nala bund (Pandy and Hiran, 1992).

\section{Side slopes}

As the material of bund is sand with clay core, therefore upstream side slope taken as 3:1 and downstream side slope taken as 2.5:1.

\section{Length of nala bund}

Length of nala bund was decided for gross height and for keeping the top surface level along a centre line of construction of nala bund.

\section{Base width of nala bund}

Base width of nala bund was estimated at different chainages along the length, after considering top width and side slopes. The equation of base width used for 3:1 and 2.5:1 side slopes was

$$
B=5.5 \mathrm{H}+\mathrm{W}
$$

Where, $\mathrm{B}=$ Bottom width of nala bund, $\mathrm{m}$ $\mathrm{H}=$ Gross height of nala bund, $\mathrm{m}$ $\mathrm{W}=$ Top width of nala bund, $\mathrm{m}$

\section{Fill volume}

Fill volume was calculated by using formula.

$$
\mathbf{V}=\left[\frac{\mathrm{A}_{1}+\mathrm{A}_{2}}{2}\right] \times \mathbf{L}
$$

Where, $\mathrm{V}=$ Volume between section, $\mathrm{m}^{3}$ $\mathrm{A}_{1}=$ Cross section area of nala bund at initial point of section, $\mathrm{m}^{2}$

$\mathrm{A}_{2}=$ Cross section area of nala bund at end point of section, $\mathrm{m}^{2}$ 
$\mathrm{L}=$ Length of section, $\mathrm{m}$

Total volume was estimated by adding the volume in different sections.

\section{Structural design}

The stability analysis of the selected structures was carried out by checking factor of safety of each structure against sliding, overturning, crushing and tension. The various forces acting on structures moments developed and other factors are calculated in each case. Singh et al., (1990) stated that a structure can fail in the following ways

It may slide forward

It may overturn

The material may get crushed due to maximum compressive stress acting normal to the section and

The tensile stress set up in the section, which may open the joints of the masonry and ease its failure. Therefore stability analysis of masonry structure should be made for safety of structure.

\section{Structure subjected to water pressure}

Weight of dam or retaining wall acting vertically downwards $\mathrm{W}$ and

Horizontal water pressure $\mathrm{P}$

The weight of dam per unit length is given by

$$
\mathrm{W}=\frac{(\mathrm{a}+\mathrm{b})}{2} \times \mathrm{H} \times \rho
$$

Where, $\mathrm{a}=$ Top width of nala bund

$\mathrm{b}=$ Bottom width of nala bund

$\mathrm{H} \quad=$ Total height of nala bund

$\rho \quad=$ Density of masonry

And this acts at a distance

$$
X=\frac{a^{2}+a b+b^{2}}{3(a+b)}
$$

The horizontal water pressure $\mathrm{P}$ is computed by using the formula for intensity of pressure of water at any depth

$$
P=\omega X
$$

Where, $\omega=$ Density of water

$\mathrm{X}=$ Depth below surface of water where pressure is measured

The horizontal water pressure is given by the area of the pressure intensity diagram

$$
\begin{aligned}
& \mathrm{P}=\frac{1}{2} \times \mathrm{h} \times \mathrm{h} \times \omega \\
& =\frac{\omega \mathrm{h}^{2}}{2}
\end{aligned}
$$

Where, $\mathrm{h}=$ depth of impounding water.

This pressure acts at a distance $\frac{\mathrm{H}}{3}$ above the base when water is impounded, the resultant force on the dam is given by $\mathrm{R}=\left(\mathrm{P}^{2}+\mathrm{W}^{2}\right)^{0.5}$ and it act at base $\mathrm{AB}$ at $\mathrm{F}$. When there is no water, the value of horizontal water pressure $\mathrm{P}$ is zero. Hence the resultant is given by $\mathrm{R}=$ $\mathrm{W}$ and it cut the base $\mathrm{AB}$ at $\mathrm{E}$. The distance $\mathrm{EF}$ is called shift of reaction $(\mathrm{Z})$. And the correlation between shift of reaction and the height of dam is given by

$$
\mathrm{Z}=\frac{\mathrm{P}}{\mathrm{W}} \times \frac{\mathrm{h}}{3}
$$

As $\mathrm{O}$ is the middle point of $\mathrm{AB}$ then

$$
\begin{aligned}
& e=O F=B F-B O \\
& e=X+Z-\frac{b}{2}
\end{aligned}
$$


Where, e = eccentricity

\section{Structure subjected to the earth pressure}

If,

$\mathrm{H}=$ Height of nala bund $(\mathrm{m})$

$\mathrm{W}_{\mathrm{e}}=$ Density of earth $\left(\mathrm{kg} \mathrm{m}^{-3}\right)$

$\mathrm{P}=$ Density of masonry $\left(\mathrm{kg} \mathrm{m}^{-3}\right)$

$\theta=$ Angle of repose of earth, degrees and a and $b=$ top and bottom width, $m$

Considering unit length of wall,

$\mathrm{P}=\frac{\mathrm{W}_{\mathrm{e}} \mathrm{H}^{2}}{2}\left[\frac{1-\sin \theta}{1+\sin \theta}\right]$

which acts at $\frac{\mathrm{H}}{3}$ above base

Now, $\mathrm{W}=$ weight of wall per unit length

$$
=\frac{(a+b)}{2} \text { H. } \rho
$$

Which acts at $\mathrm{X}$ for the vertical face $\mathrm{BC}$ and is given by

$$
X=\frac{a^{2}+a b+b^{2}}{3(a+b)}
$$

Eccentricity, $e=X+Z-\frac{b}{2}$

The maximum and minimum stress intensities acting normal to the base can be found by applying the equation.

$$
\begin{aligned}
f_{\max }= & \frac{W}{b}\left[1+\frac{6 e}{b}\right] \\
f_{\min }= & \frac{W}{b}\left[1-\frac{6 e}{b}\right]
\end{aligned}
$$

\section{Condition for stability of structure}

Structure was tested for Safety against sliding, Safety against overturning, Safety against crushing and Safety against tensile stress

\section{Results and Discussion}

The nala bund was designed by considering 25 years rainfall data available at Agrometeorological Observatory, College of Agriculture, DBSKKV, Dapoli. Volume of runoff was estimated by using Curve Number method $\left(84,448.8 \mathrm{~m}^{3}\right.$ and $\left.84,981.6 \mathrm{~m}^{3}\right)$ for the weekly maximum rainfall $(867.4 \mathrm{~mm})$ in 25 years return period for earthen nala bund.

The peak rate of runoff $\left(1.72 \mathrm{~m}^{3} / \mathrm{s}\right)$ for the design of earthen nala bunds were computed by using the Rational method. The dimensions of emergency flood spillway were selected in such a way that the discharge passing through flood spillway is greater than peak runoff rate.

The total earthwork $\left(1313.85 \mathrm{~m}^{3}\right.$ and $\left.1857 \mathrm{~m}^{3}\right)$ for the nala bund was computed. Structure was tested for Safety against sliding, Safety against overturning, Safety against crushing and Safety against tensile stress. It was observed that structure was safe against all. From the analysis of data and results obtained from comparison between existing and designed dimensions of nala bunds following conclusions are deduced.

For existing and standard designed dimensions of earthen nala bund structure ENB, there was significant difference between standard design and existing structures viz., height of nala bund, top width, base width and side slopes.

The depth of existing flood spillways for both the earthen nala bunds was found to be more than the desired depth. The 
velocities of flow of water through the design sections of flood spillway were within safe limit.

The cost of construction of existing nala bunds were found to be higher than the cost calculated for the structure, designed by the standard procedure.

Stability analysis revealed that all selected nala bund were found to be safe from stability analysis.

Due to more freeboard and more flow depth in flood spillway, dimension of earthen nala bund increases such as height of nala bund, top width, base width of structures.

In case of existing earthen nala bunds, side slopes should be flatter $(\mathrm{u} / \mathrm{s} 3: 1$ and $\mathrm{d} / \mathrm{s} 2.5: 1$ ) so as to suit the fill material.

The cost of construction of earthen nala bunds computed by Department was found to be 37.32 per cent higher than the actual cost calculated by the standard design procedure.

\section{References}

Anonymous. 2003. Watershed development gazette, developed by State Department of Agricultural Maharashtra State, Govt. Publication, Pune-1.

MahaleDilip, R.T. Thokal, B.G. Malankar, D.D. Satvalekar, S.B.Nandgude, A.G. Powar and M.R. More. 2004. Effect of soil and water conservation measures on groundwater recharge in Priyadarshini watershed. Integrated Water Resources: Planning and Management, pp.349-356.

Pandy, V.K. and K.S. Hiran. 1992. Earthen embankment reservoir planning for water harvesting, A case study of Vagpura watershed. Indian J. of Soil Conservation, 20 (3) : 39-47.

Schwab, G.O., R.K. Frevert, T.W. Ediminster and K.K. Barnes. 1981. Soil and Water Conservation Engineering. (Third Edition), Johns Wiley and Sons, Inc., New York, pp.221-240.

Singh, G., G. Sastry, C. Venkatraman and B.P. Joshi. 1990. Manual of Soil and Water Conservation Practices. Oxford and IBH Publishing Co. Pvt. Ltd., New Delhi.

Singh, G., G. Sastry and S. P. Bhardwaj. 1990. Watershed responses to conservation measures under different Agro-climatic regions of India. Indian J. of Soil Conservation, 18 (3) : 16-22.

Singh, R. 2003. Watershed Planning and Management.Yash Publication house, Jaipur pp 147-149.

Suresh, R. 1997. Soil and Water Conservation Engineering, Standard Publishers Distributors, Delhi.

Tideman, E.M. 2003. Watershed Management Guideline for Indian Conditions, Omega Scientific Publisher, New Delhi, pp 9295.

\section{How to cite this article:}

Bhange. H. N., S. S. Idate, B. L. Ayare, R. M. Dharaskar, G. G. Kadam and Kolhe. P. R. 2020. Evaluation of Earthen Nala Bund in Small Watershed: A Case Study. Int.J.Curr.Microbiol.App.Sci. 9(06): 1748-1753. doi: https://doi.org/10.20546/ijcmas.2020.906.217 